\title{
Corporate Social Responsibility Strategy and Its Influence Over Consumer Purchasing Decisions in Financial Institutions
}

\author{
Matthew Tinker \\ University of Newcastle, New South Wales, Australia \\ Lisa Barnes \\ Conjoint University of Newcastle, New South Wales, Australia \\ David Wilson \\ Avondale College of Higher Education, New South Wales, Australia
}

\begin{abstract}
The aim of this research is how corporate social responsibility (CSR) activities can influence the purchasing behaviour of consumers. When it comes to financial institutions, there have been significant amounts of literature written on CSR and there is still a gap in understanding how CSR activities influence consumer's perception. This gap is particularly evident in the financial services sector, given they are the largest contributors to CSR in Australia. In addressing the research problem, the study focuses on understanding the most influential CSR initiatives, understanding how the influence of CSR initiatives can change depending on situational context, and understanding how demographic attributes can alter perception. A questionnaire was answered by 1,014 respondents, showing to be sufficiently representative of the Australian population. The outcomes of this research were used to develop a comprehensive framework for Australian Financial Institutions (AFI) to use when developing their CSR strategy. It was clear that across all investment types and situational contexts, community support was the most influential form of CSR across the sample. Whilst this was the case, the level of influence differed across demographic groups and changed to varying degrees based on situational context dependent on the respondent. Community support's influence as a CSR initiative was clearly ahead of others presented to the respondents followed by employee support and environment dependent on the investment method and the situational context.
\end{abstract}

Keywords: corporate social responsibility (CSR), consumer purchasing decisions, financial institutions

\section{Introduction}

The theory of corporate social responsibility (CSR) grew in popularity throughout academic literature from the early 1960s. The work of Bowen (1953) became a popular reference point for the way that "businessmen" were to conduct themselves. CSR refers to the continuing commitment by business to behave ethically and contribute to economic development, while improving the quality of life of the workforce and

Matthew Tinker, DBA, associate professor, School of Business, University of Newcastle.

Lisa Barnes, DBA, associate professor, head of Avondale Business School, Avondale College of Higher Education, Conjoint University of Newcastle.

David Wilson, CPA, lecturer, Avondale Business School, Avondale College of Higher Education. 
their families as well as of the local community and society at large (World Business Council for Sustainable Development [WBCSD], 1999, p. 3). Whilst this definition is provided by WBCSD, there have been many different definitions provided over time. However, the key view of these definitions is undertaking their actions and decisions in a socially responsible way, so as not to have detrimental impacts over employees, environment, the local community, or society in general.

In attempting to clear up ambiguity of CSR understanding, a number of writers developed models of CSR, although there was a clear and concise outline of the inputs and outputs of CSR, which was developed by Bhattacharya and Sen (2004). Bhattacharya and Sen's work had been used as the frame of reference for this dissertation, as it is used widely in the area of CSR as a key piece of literature on the topic of CSR. After extensive research, it was also identified that Bhattacharya and Sen's Framework was the most comprehensive upon which to base this study. The framework encompasses a range of important areas relative to CSR, including the inputs and outputs of CSR activities, along with internal and external outcomes as well as consumer and cause (Bhattacharya \& Sen, 2004). The work by Bhattacharya and Sen introduced the six CSR initiatives:

1. Community support: defined as supporting community initiatives, including but not limited to support of arts and health programs, educational and housing initiatives for the economically disadvantaged, and generous/innovative giving;

2. Diversity: defined as support for equality initiatives in areas, including but not limited to gender, race, family, sexual orientation, and disability;

3. Employee support: defined as supporting initiatives focusing on employees, including a company's concern for safety, job security, profit-sharing, union relations, and employee involvement;

4. Environment: defined as the support of initiatives supporting the environment, including but not limited to production of environment friendly products, hazardous waste management, use of ozone-depleting chemicals, animal testing, pollution control, and recycling;

5. Non-U.S. operations (defined for the purpose of this research on a global scale as overseas operational practices): defined as the way in which a company conducts itself both on- and off- shore, including but not limited to its overseas labor practices (including sweatshops) and operations in countries with human rights violations;

6. Product: defined as a company's focus on the goods or service they produce and how it is produced, including but not limited to product safety, research and development ( $R$ \& $D$ )/innovation, marketing/contracting controversies, and antitrust disputes.

They also outline the investment methods of money/goods, time/personnel, and intangible investment (Bhattacharya \& Sen, 2004). A key piece of the Bhattacharya and Sen's (2004) work is the outputs of the CSR activities. An important consideration for business is the outcome of consumer purchasing intent, an outcome that has been found to occur when there is awareness of CSR initiatives that an organization participates in (Sen, Bhattacharya, \& Korschun, 2006; Grimmer \& Bingham, 2013). Ultimately, businesses thinking commercially about their CSR initiatives should be seeking their activities to influence consumer purchasing behaviour. A number of researchers have shown that CSR can influence purchasing intention, which is generally deemed to be a strong indicator of purchasing behaviour (Morwitz, Steckel, \& Gupta, 2007). Past research had found consumer's perception of CSR initiatives to be influential on purchasing behaviour (Creyer \& Ross, 1997; Maignan, 2001; Muller \& Whiteman, 2009) and there is limited understanding of the sources of CSR that are 
most influential (Mohr, Webb, \& Harris, 2001). This research seeks to close a part of this existing gap.

\section{Literature Review}

\section{Financial Institutions}

Financial institutions are the largest contributor to CSR in Australia (Australia Centre for Corporate Social Responsibility [ACCSR], 2011) yet, there is little research to demonstrate the benefit of CSR on consumer's perception of financial institutions as a result. One strong example that raises questions as to the benefit of CSR investment is the work of Pomering and Dolnicar (2009) on the Australian banking sector, where they identified that there is limited awareness of the CSR initiatives of these institutions. It has been identified that awareness of CSR initiatives are low in general (Bhattacharya \& Sen, 2004; Sen, Bhattacharya, \& Korschun, 2006). However, it must be considered, whether this is due to poor execution of programs, as it has been found that when consumers were aware of a company's CSR initiatives. They have significantly more positive views of the focal company in terms of their associations, attitudes, identification, and behavioural intentions (Sen, Bhattacharya \& Korschun, 2006, p. 164). It is important then that a company understands their potential consumer base and make investment carefully and appropriately to raise awareness (Alsop, 2002; Sen, Bhattacharya, \& Khorshun, 2006). With CSR programs getting increased attention, it is important that programs are well thought out and considered in line with consumer views.

Increasingly with greater access to information and more channels to have information published, there is greater focus on companies to do the right thing (Creyer \& Ross, 1997). With the increased availability of information, it is important that businesses conduct themselves in a socially responsible manner. Otherwise, the risk of negative information can cause significant harm to operations. Since Bowen (1953) introduced CSR, the importance of the topic had increased, as there was increasing expectation from the community for organization to act in a responsible manner and be transparent in their approach (Creyer \& Ross, 1997; Kotler \& Lee, 2005; Podnar \& Golab, 2007). Their significant contribution to CSR is considered by Australian Financial Institutions (AFI) as a way to position their brand positively (McDonald \& Rundle-Thiele, 2008; Pomering \& Dolnicar, 2009) and there has been empirical research that found that investment in CSR initiatives can gain strategic advantage and position (Fuller, 2010). Despite this empirical research, Pomering and Dolnicar (2009) found that Australian banks were unable to gain this level of advantage, as there was a lack of awareness of CSR initiatives undertaken by Australian banks within the Australian population, which may suggest the CSR strategy undertaken was not well-planned or well-strategized.

\section{Financial Institutions and CSR}

Traditionally large contributors to social response have been financial institutions. Financial institutions whether correctly or not have had to take a large share of the blame for the events of the financial crisis. It is important that in looking at CSR for financial institutions that we understand how their programs have evolved since this time. Before the financial crisis (McDonald \& Rundle-Thiele, 2008), the investment from financial institutions on CSR programs was increasing off the back of increased understanding from these companies of the importance of these programs. Condosta (2012) found in a study of the Italian banking system that this investment continued their programs through the years post the financial crisis yet. The study from Condosta was limited, due to its limited breadth and the nature, for which it established its results, a point acknowledged by its writer. A different approach was taken by Pomering and Dolnicar (2009) who researched consumer 
awareness of the contributions by Australian banks. Through this research, they identified that the key driver for involvement in these programs is seen as a good way to overcome their bad reputation, because it is seen as a good way to re-engage with the community. However, despite sizeable investment the majority of their CSR activities go unnoticed.

It is argued in agency theory that participation in CSR activities is not in the best interests of an organization (Friedman, 1970), so in times of economic difficulty, it could be argued that a company needs to protect their prosperity or stability, and thus, be careful with their investments. Multiple researchers explored the notion that companies may have retracted their investment in CSR to protect their economic position in this uncertain time and found that this occurred with the cost of these activities being a major factor, which was the finding of other research as well (J. Nasi, S. Nasi, Phillips, \& Zyglidopoulos, 1997; Trebeck, 2008, Giannarakis \& Theotokas, 2011). However, Giannarakis and Theotokas (2011) also argued that CSR and its cost should not only be seen as a threat, but also a great opportunity. Literature on the subject of CSR often suggests that in times of economic difficulty that organizations should cut spending on social responsibility programs, but in these times, there is a strong opportunity to build brand awareness and consumer trust (Giannarakis \& Theotokas, 2011), which is important for any organization.

CSR has been a consideration for many companies, including financial institutions. As a method for increasing their reputational status and this was found to be true by Pomering and Dolnicar (2009) when they identified that Australian banks have accepted it as one way to highlight that they are contributing to society to position their brand positively. Empirical research by Fuller (2010) found that an organization could gain advantage and strategic position by contribution towards CSR programs, a finding that supported the concept of stakeholder theory. It has become an expectation that a company would derive benefit from benefitting others (Kemper \& Martin, 2010). However, it has been found that after the financial crisis that significant damage has been cased due to the benefits of CSR being outweighed by their cost (Kemper \& Martin, 2010). Opposing this argument was the view from Manubens (2009) that contribution to CSR programs today would provide strength to the communities in which the company operated and in effect, the long term interests of an organization. The literature on CSR points toward great benefit to organizational reputation and as such financial institutions should pursue these programs. However, there is research required to understand the approach that should be taken to gain maximum benefit from the investment in these programs.

\section{Research Problem}

Comprehension of CSR becomes increasingly important particularly to AFI, given their significant investment into CSR (ACCSR, 2011). The importance of comprehension amongst financial institutions was however questioned by Pomering and Dolnicar (2009) as they identified a need for further research on this subject. However, there is a significant gap in the current literature, given the fact that AFI invest so greatly in CSR every year (ACCSR, 2011) and that is research into the forms of CSR activities that lead to the largest benefit in terms of consumer's perception towards a particular organization. This leads to the research problem-How does CSR activity influence the purchasing behaviour of AFI consumers?

From this overarching research problem, we develop three further research questions to assist the comprehension of this important topic and to provide an understanding of the influential forms of CSR over consumer's perceptions of AFI. The research questions are:

1. To what extent does CSR activity influence the purchasing behaviour of AFI customers? 
2. What CSR initiatives are the most effective at improving consumer's perceptions of AFI?

3. Do perceptions of CSR initiatives in AFI differ across socio-demographical groups?

Through answering these research questions, it will provide an important insight into the benefit of understanding the types of CSR activities that influence consumer's perceptions and can influence their purchasing decisions.

\section{Research Methodology}

The research design put in place seeks to answer the three key research questions posed to understand the research problem. These questions have been broken down and understood in terms of dependent, independent, moderating, and mediating variables. The dependent variable of this study is consumer's perception with the independent variable being CSR initiative. CSR activity type acts as a mediating variable with investment method being a moderating variable along with situational context and socio-demographics. The research uses a questionnaire to address the existing gaps in the literature and surveys a representative sample of the Australian population.

Table 1

Summary of Descriptive Statistics

\begin{tabular}{|c|c|c|c|}
\hline & & Count & Probability (\%) \\
\hline \multirow{2}{*}{ Gender } & Male & 500 & 49.31 \\
\hline & Female & 514 & 50.69 \\
\hline \multirow{6}{*}{ Age } & $18-20$ years old & 36 & 3.55 \\
\hline & 21-30 years old & 181 & 17.85 \\
\hline & 31-40 years old & 180 & 17.75 \\
\hline & 41-50 years old & 182 & 17.95 \\
\hline & $51-60$ years old & 170 & 16.77 \\
\hline & $60^{+}$years old & 265 & 26.13 \\
\hline \multirow{5}{*}{ Level of education } & High school year 10 & 127 & 12.52 \\
\hline & High school year 12 & 164 & 16.17 \\
\hline & Technical and further education (TAFE) certificate/diploma & 311 & 30.67 \\
\hline & Undergraduate & 230 & 22.68 \\
\hline & Postgraduate & 182 & 17.95 \\
\hline \multirow{9}{*}{ Household income } & Negative income & 9 & 0.89 \\
\hline & Nil income & 24 & 2.37 \\
\hline & $\$ 1-\$ 19,999$ & 64 & 6.31 \\
\hline & $\$ 20,000-\$ 49,999$ & 266 & 26.23 \\
\hline & $\$ 50,000-\$ 99,999$ & 350 & 34.52 \\
\hline & $\$ 100,000-\$ 149,999$ & 173 & 17.06 \\
\hline & $\$ 150,000-\$ 199,999$ & 75 & 7.40 \\
\hline & $\$ 200,000-\$ 249,999$ & 26 & 2.56 \\
\hline & $\$ 250,000^{+}$ & 27 & 2.66 \\
\hline \multirow{8}{*}{ Number of products } & 1 & 243 & 23.96 \\
\hline & 2 & 310 & 30.57 \\
\hline & 3 & 310 & 30.57 \\
\hline & 4 & 108 & 10.65 \\
\hline & 5 & 28 & 2.76 \\
\hline & 6 & 7 & 0.69 \\
\hline & 7 & 7 & 0.69 \\
\hline & 8 & 1 & 0.10 \\
\hline
\end{tabular}


The sample for this research is based on a socio-demographic sample of the Australian population based on the 2011 census, using the age of 18 years old as the starting point and given this represents the age of majority in Australia (Property and Contracts Act in New South Wales [NSW], 1970; Age of Majority Act in Queensland [QLD], 1974). This provides for a base of slightly more that 15.9 million people (Australian Bureau of Statistics, 2013) applied to this is a 5\% margin of error, a $99 \%$ confidence level, and a $50 \%$ response distribution to provide a calculated sample size of 664 . The sample was then extended to 1,000 individuals to improve the sample (see Table 1).

Respondents are presented with a web-based survey, which only becomes accessible following accepting to participate in the research, which is put in place to ensure ethical obligations are met. Collection of the data comes in the form of best-worst scaling (BWS) which assumes a level of ordinality (Louviere \& Woodworth, 1990). BWS observes the cognitive process of the respondents in their selection among similar sets of options (Finn \& Louviere, 1992). The responses provide good insight into the differences in the eyes of the respondents regarding the specific independent variable. The sets of questions posed to the respondents use Bhattacharya and Sen's (2004) six CSR activity types across three investment types a model that has been chosen, as it provides a good understanding of CSR initiatives.

\section{Results of Data Analysis}

Bhattacharya and Sen (2004) used six high-level CSR initiatives in the corporate social ratings monitor to rate companies CSR records. These six CSR initiatives are community support, diversity, employee support, environment, non-U.S. operations (which is better defined on a global scale as overseas operational practices) and product (Bhattacharya \& Sen, 2004). Then, they outlined that the investment in these activities could be in the form of money or goods, time and personnel, and intangible assets (Bhattacharya \& Sen, 2004, p. 14). Table 2 outlines the comparison of the six CSR initiatives across the three investment activities, and then, if the investment activity would change in a crisis.

Table 2

Comparison Across All Investment Types and CSR Activity Type

\begin{tabular}{lccccccc}
\hline & $\begin{array}{l}\text { Financial } \\
\text { investment } \\
\text { (\%) }\end{array}$ & $\begin{array}{l}\text { Financial } \\
\text { Crisis (\%) }\end{array}$ & $\begin{array}{l}\text { Human resource } \\
\text { investment (\%) }\end{array}$ & $\begin{array}{l}\text { Human resource } \\
\text { investment in } \\
\text { crisis (\%) }\end{array}$ & $\begin{array}{l}\text { Intangible } \\
\text { investment (\%) }\end{array}$ & $\begin{array}{l}\text { Intangible } \\
\text { investment } \\
\text { in crisis (\%) }\end{array}$ & $\begin{array}{l}\text { Average } \\
\text { percentage } \\
\text { of cases } \\
\text { (\%) }\end{array}$ \\
\hline Community support & 40.80 & 41.80 & 41.70 & 55.50 & 38.70 & 53.70 & 45.37 \\
Diversity & 11.10 & 9.30 & 12.10 & 8.10 & 12.60 & 7.60 & 10.13 \\
Environment & 14.40 & 12.40 & 11.00 & 16.00 & 13.60 & 18.60 & 14.33 \\
Non-US operations & 3.80 & 6.30 & 4.30 & 3.30 & 5.40 & 2.70 & 4.30 \\
Employee support & 19.60 & 21.80 & 20.10 & 13.00 & 14.00 & 12.70 & 16.87 \\
Product & 10.20 & 8.40 & 10.70 & 4.10 & 15.70 & 4.60 & 8.95 \\
Total & 100.00 & 100.00 & 100.00 & 100.00 & 100.00 & 100.00 & 100.00 \\
\hline
\end{tabular}

In understanding the demographic profile that is most influenced by the CSR initiatives of a financial institution (see Table 3), the analysis shows that whilst within each of the demographic criteria, there is clearly groups that are more likely to be influenced. It includes females, the younger age groups, and the higher income households. There are some profiles that show significantly higher likelihood of influence, which include households whose income is between $\$ 200,000$ and $\$ 249,999$, and respondents with six or more product types. 
There were also some groups that were significantly below the average of the sample's likelihood of being influence by the CSR initiatives of a financial institution. It includes negative income households (55.56\%), households with incomes between \$1 and \$19,999 (56.25\%), and respondents with the highest educational level of high school year (60.63\%).

The analysis was able to show that the CSR initiatives of a financial institution were influential across the majority of respondents in the sample choice to use their products or services. Whilst it was seen to be influential by all the level of influence changed depending on the demographic profile of the respondent.

Table 3

Influence of CSR Summary

\begin{tabular}{|c|c|c|c|c|c|c|c|c|c|}
\hline & Characteristic & $\begin{array}{l}\text { CSR is } \\
\text { influential }\end{array}$ & $\begin{array}{l}\text { CSR is not } \\
\text { influential }\end{array}$ & Total & $\begin{array}{l}\text { Influential by } \\
\text { Attribute/Tota } \\
\text { l Attribute (\%) }\end{array}$ & $\begin{array}{l}\text { Not Influential } \\
\text { by } \\
\text { Attribute/Tota } \\
\text { l Attribute (\%) }\end{array}$ & $\begin{array}{l}\text { Influential } \\
\text { by } \\
\text { Attribute/To } \\
\text { tal responses } \\
\text { (\%) }\end{array}$ & $\begin{array}{l}\text { Not } \\
\text { Influential by } \\
\text { Attribute/Tot } \\
\text { al responses } \\
(\%)\end{array}$ & $\begin{array}{l}\text { Total } \\
\text { responses of } \\
\text { Attribute/To } \\
\text { tal responses } \\
\text { (\%) }\end{array}$ \\
\hline \multirow{2}{*}{ 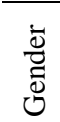 } & Male & 337 & 163 & 500 & 67.40 & 32.60 & 33.23 & 16.07 & 49.31 \\
\hline & Female & 368 & 146 & 514 & 71.60 & 28.40 & 36.29 & 14.40 & 50.69 \\
\hline \multirow{6}{*}{ 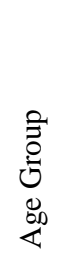 } & $18-20$ years old & 28 & 8 & 36 & 77.78 & 22.22 & 2.76 & 0.79 & 3.55 \\
\hline & 21-30 years old & 136 & 45 & 181 & 75.14 & 24.86 & 13.41 & 4.44 & 17.85 \\
\hline & $31-40$ years old & 130 & 50 & 180 & 72.22 & 27.78 & 12.82 & 4.93 & 17.75 \\
\hline & 41-50 years old & 119 & 63 & 182 & 65.38 & 34.62 & 11.74 & 6.21 & 17.95 \\
\hline & 51-60 years old & 118 & 52 & 170 & 69.41 & 30.59 & 11.64 & 5.13 & 16.77 \\
\hline & $60^{+}$years old & 174 & 91 & 265 & 65.66 & 34.34 & 17.16 & 8.97 & 26.13 \\
\hline \multirow{9}{*}{ 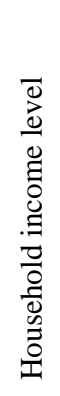 } & Negative income & 5 & 4 & 9 & 55.56 & 44.44 & 0.49 & 0.39 & 0.89 \\
\hline & Nil income & 18 & 6 & 24 & 75.00 & 25.00 & 1.78 & 0.59 & 2.37 \\
\hline & \$1-\$19,999 & 36 & 28 & 64 & 56.25 & 43.75 & 3.55 & 2.76 & 6.31 \\
\hline & $\$ 20,000-\$ 49,999$ & 187 & 79 & 266 & 70.30 & 29.70 & 18.44 & 7.79 & 26.23 \\
\hline & $\$ 50,000-\$ 99,999$ & 238 & 112 & 350 & 68.00 & 32.00 & 23.47 & 11.05 & 34.52 \\
\hline & $\$ 100,000-\$ 149,999$ & 124 & 49 & 173 & 71.68 & 28.32 & 12.23 & 4.83 & 17.06 \\
\hline & $\$ 150,000-\$ 199,999$ & 55 & 20 & 75 & 73.33 & 26.67 & 5.42 & 1.97 & 7.40 \\
\hline & $\$ 200,000-\$ 249,999$ & 22 & 4 & 26 & 84.62 & 15.38 & 2.17 & 0.39 & 2.56 \\
\hline & $\$ 250,000^{+}$ & 20 & 7 & 27 & 74.07 & 25.93 & 1.97 & 0.69 & 2.66 \\
\hline \multirow{5}{*}{ 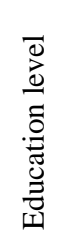 } & High school year 10 & 77 & 50 & 127 & 60.63 & 39.37 & 7.59 & 4.93 & 12.52 \\
\hline & High school year 12 & 101 & 63 & 164 & 61.59 & 38.41 & 9.96 & 6.21 & 16.17 \\
\hline & $\begin{array}{l}\text { TAFE } \\
\text { certificate/Diploma }\end{array}$ & 207 & 104 & 311 & 66.56 & 33.44 & 20.41 & 10.26 & 30.67 \\
\hline & Undergraduate & 177 & 53 & 230 & 76.96 & 23.04 & 17.46 & 5.23 & 22.68 \\
\hline & Postgraduate & 143 & 39 & 182 & 78.57 & 21.43 & 14.10 & 3.85 & 17.95 \\
\hline \multirow{8}{*}{ 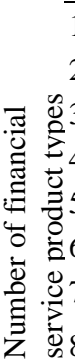 } & 1 & 158 & 85 & 243 & 65.0 & 34.98 & 15.58 & 8.38 & 23.96 \\
\hline & 2 & 205 & 105 & 310 & 66.13 & 33.87 & 20.22 & 10.36 & 30.57 \\
\hline & & 216 & 94 & 310 & 69.68 & 30.32 & 21.30 & 9.27 & 30.57 \\
\hline & & 91 & 17 & 108 & 84.26 & 15.74 & 8.97 & 1.68 & 10.65 \\
\hline & & 21 & 7 & 28 & 75.00 & 25.00 & 2.07 & 0.69 & 2.76 \\
\hline & & 6 & 1 & 7 & 85.71 & 14.29 & 0.59 & 0.10 & 0.69 \\
\hline & & 7 & 0 & 7 & 100.00 & 0.00 & 0.69 & 0.00 & 0.69 \\
\hline & & 1 & 0 & 1 & 100.00 & 0.00 & 0.10 & 0.00 & 0.10 \\
\hline
\end{tabular}




\section{Discussion}

The first research question asked as part of this dissertation was whether there were CSR initiatives were influential over consumer purchasing decisions. This research shows that almost $70 \%$ of the sample is influenced in their choice to use the products or services of a financial institution by the CSR program of the financial institution. Then, Research Question 2 explored this further and there were six CSR categories that were explored based on Bhattacharya and Sen's (2004) Framework and from this it was identified that community support was the most influential CSR initiative. It was also identified through the rank-order analysis that employee support and environment are also likely to influence the sample. Other three initiatives (diversity, product, and non-US operations) have low levels of influence over the sample when implemented by AFI.

Following this, the final research question that was raised in this dissertation was Research Question 3, "What CSR initiatives are the most effective at improving consumer's perceptions of AFI?" It was identified that demographic characteristics play an important role in the perception towards CSR initiatives across all of the demographic attributes that were reviewed as part of this research, which included gender, age, level of education, household income level, and number of financial products held by the respondent. Similar outcomes had been found in the research of others, including Arlow (1991) who found that characteristics of respondents among college students played a key role in their evaluation of CSR, as Miesing and Preble (1985) did. Furthermore, this study seems to confirm the findings by Arlow (1991), Burton and Hegarty (1999), and Panwar, Han, and Hansen (2010) that females were more socially responsible than males. It also supports Arlow's (1991) view that age was the most influential demographic characteristic.

Outside of age and gender, the research that was conducted also looked at level of education, number of products held by the respondent and household income levels. When looking at the level of education of the respondents, it is found that the higher the level of education, the greater expectation towards CSR initiatives. A finding that is consistent with Quazi (1997) who contended that there was a significant relationship between education level and a person's perception of CSR initiatives. There was also found to be differences in the view of respondents based on the number of products that they hold with the respondents becoming more likely to be influenced by CSR the more products that they hold from one to four products.

However, beyond four products does not hold significant substance due to the small sample size. The other demographic characteristics that this research looked at were that of household income levels an area that was identified to be a factor. In the influence of CSR initiatives with higher income households being more significantly influenced by CSR than lower income households, despite previous research being unable to draw conclusions on this characteristics influence (Graafland \& Mazereeuw-Van, 2012).

The findings of this research also provide further clarity on past research that has identified that consumers believe that companies should engage in social responsibility initiatives (J. Nasi, S. Nasi, Phillips, \& Zyglidopoulos, 1997; Yoon, Gurhan-Canli, \& Schwarz, 2006; Oberseder, Schlegelmilch, \& Murphy, 2013).

\section{Conclusions}

Through this research, it is proposed that there are three key strategic consideration areas for any business when developing a CSR strategy which can be simply outlined as: 
1. Investment type: The form of investment that a company is willing to make into their CSR program, which can fall into the three categories of financial investment, investment of human resource, or intangible investment;

2. Demographics: The type of consumer that they are aiming to attract. This is important as the demographic characteristics of the company's target audience may find one form of CSR more influential than another;

3. Situational context: The situational context is important, as has been found in this study, as the level of influence of a CSR initiative can change depending on the situational context.

This model should be viewed in line with the proposed CSR initiatives to ensure that the optimum CSR initiatives and strategy are developed for the benefit of an organization that uses the model (see Figure 1).

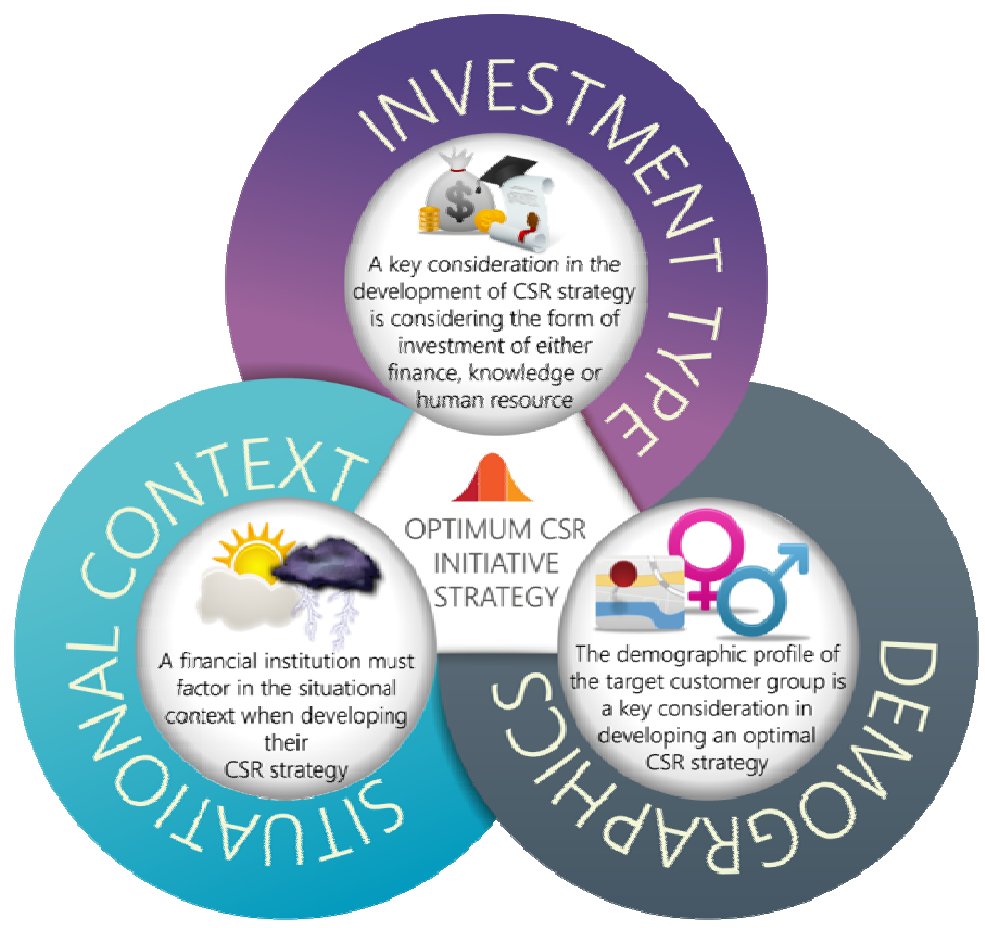

Figure 1. CSR strategic considerations model.

The outcome of this research is the ability for AFI to develop an optimal CSR strategy that when applied will provide the greatest return on investment. The considerations to achieve this outcome are detailed with the CSR strategic investment application (SIA) framework that is detailed in Figure 2. The SIA framework covers four key areas that when all considered and put into practice will arrive at the optimum point within a CSR strategy for an AFI.

The four key areas to consider when developing a CSR strategy for AFI:

1. What CSR initiatives have the potential to influence consumers to use the products or services of their institution?

2. The factors that impact a customer's view of CSR initiatives;

3. The potential influence that the institution has to implement CSR initiatives;

4. What would influence the institution not to implement CSR? 
When these factors are considered, it is the contention of this research that the optimal CSR strategy can be achieved for AFI.

The objective of this research was to understand the influence CSR initiatives on consumer's perception of AFI. This research has identified that CSR activities undertaken by financial institutions are influential to the majority (70\%) of the sample and that community support initiatives are the most influential on consumer's perception no matter the form of investment or situational context. This research also serves as a foundation for future research in this area that can be built upon for the benefit of a broader range of industry sectors. The outcome of the research showed that community support is, no matter the circumstance, the most influential CSR initiative on the Australian population. However, depending on the investment method and the situational context the second most influential can change between employee support and environment. The research also shows that socio-demographic profile will greatly affect the influence a CSR initiative type has on a person.

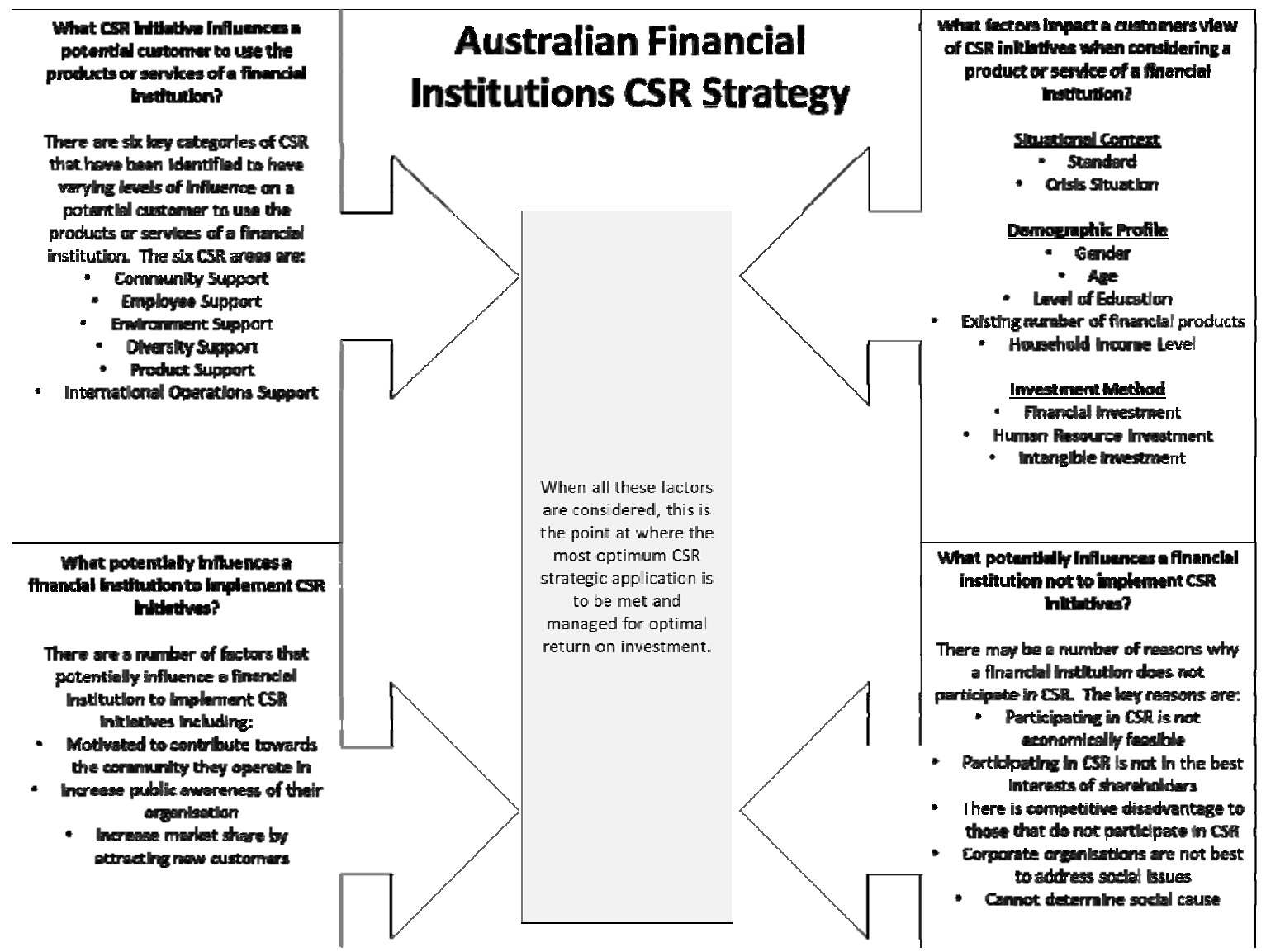

Figure 2. CSR SIA Framework.

\section{References}

Alsop, R. (2002, January). For a company, charitable works are best carried out discreetly. The Wall Street Journal, 16.

Arlow, P. (1991). Personal characteristics in college students' evaluations of business ethics and corporate social responsibility. Journal of Business Ethics, 10(1), 63-69.

Australian Bureau of Statistics. (2011). 2011 census quick stats. Retrieved July 4, 2013, from http://www.censusdata.abs. gov.au/census_services/getproduct/census/2011/quickstat/0

Australia Centre for Corporate Social Responsibility (ACCSR). (2011). The state of CSR in Australia. In Annual Review 2010/2011: Industry Snapshot (pp. 1-8). Australia. 
Bhattacharya, C. B., \& Sen, S. (2004). Doing better at doing good: When, why, and how consumers respond to social initiatives. California Management Review, 47(1), 9-24.

Bowen, H. R. (1953). Social responsibilities of the businessmen. New York, N.Y.: Harper.

Burton, B. K., \& Hegarty, W. H. (1999). Some determinants of student corporate social responsibility orientation. Business \& society, 38(2), 188-205.

Condosta, L. (2012). How banks are supporting local economies facing the current financial crisis: An Italian perspective. International Journal of Bank Marketing, 30(6), 485-502.

Creyer, E. H., \& Ross Jr., W. T. (1997). The influence of firm behaviour on purchase intention: Do consumers really care about business ethics? Journal of Consumer Marketing, 14(6), 421-432.

Finn, A., \& Louviere, J. J. (1992). Determining the appropriate response to evidence of public concern. Journal of Public Policy and Marketing, 11(1), 12-25.

Friedman, M. (1970, September). The social responsibility of business is to increase its profits. New York Times Magazine, 13.

Fuller, M. (2010). A social responsiveness approach to stakeholder management: Lessons from the Canadian banking sector. Journal of Leadership, Accountability, and Ethics, 8(2), 51-69.

Galesic, M., \& Bosnjak, M. (2009). Effects of questionnaire length on participation and indicators of response quality in a web survey. Public Opinion Quarterly, 73(2), 349-360.

Giannarakis, G., \& Theotokas, I. (2011). The effect of financial crisis in corporate social responsibility performance. International Journal of Marketing Studies, 3(1), 2-10.

Graafland, J., \& Mazereeuw-Van, der D. S. C. (2012). Motives for corporate social responsibility. De Economist, 160(4), 377-396.

Grimmer, M., \& Bingham, T. (2013). Company environmental performance and consumer purchase intentions. Journal of Business Research, 66(10), 1945-1953.

Kemper, A., \& Martin, R. L. (2010). After the fall: The global financial crisis as a test of corporate social responsibility theories, European Management Review, 7, 229-239.

Kotler, P., \& Lee, N. (2005). Corporate social responsibility. Hoboken, New Jersey: Wiley.

Leonidou, L. C., Kvasova, O., Leonidou, C. N., \& Chari, S. (2013). Business unethicality as an impediment to consumer trust: The moderating role of demographic and cultural characteristics. Journal of Business Ethics, 112(3), 397-415.

Louviere, J. J., \& Woodworth, G. G. (1990). Best-worst scaling: A model for largest difference judgments (Working Paper, Faculty of Business, University of Alberta).

Maignan, I. (2001). Consumer's perceptions of corporate social responsibilities: A cross-cultural comparison. Journal of Business Ethics, 30(1), 57-72.

Manubens, M. (2009). Corporate social responsibility in an economic crisis: An opportunity for renewal. Global Business and Organizational Excellence, 29(1), 50-60.

McDonald, L. M., \& Lai, C. H. (2011). Impact of corporate social responsibility initiatives on Taiwanese banking customers. International Journal of Bank Marketing, 29(1), 50-63.

McDonald, L. M., \& Rundle-Thiele, S. (2008). Corporate social responsibility and bank customer satisfaction: A research agenda. International Journal of Bank Marketing, 29(1), 50-63.

Miesing, P., \& Preble, J. F. (1985). A comparison of five business philosophies. Journal of Business Ethics, 4(6), 465-476.

Mohr, L. A., \& Webb, D. J. (2005). The effects of corporate social responsibility and price on consumer responses. Journal of Consumer Affairs, 39(1), 121-147.

Morwitz, V. G., Steckel, J. H., \& Gupta, A. (2007). When do purchase intentions predict sales? International Journal of Forecasting, 23(3), 347-364.

Muller, A., \& Whiteman, G. (2009). Exploring the geography of corporate philanthropic disaster response: A study of fortune global 500 firms. Journal of Business Ethics, 84(4), 589-603.

Nasi, J., Nasi, S., Phillips, N., \& Zyglidopoulos, S. (1997). The evolution of corporate social responsiveness: An exploratory study of finnish and canadian forestry companies. Business and Society, 36(3), 296-321.

Oberseder, M., Schlegelmilch, B. B., \& Murphy, P. E. (2013). CSR practices and consumer's perceptions. Journal of Business Research, 66(10), 1839-1851.

Panwar, R., Han, X., \& Hansen, E. (2010). A demographic examination of societal views regarding corporate social responsibility in the US forest products industry. Forest Policy and Economics, 12(2), 121-128. 
Podnar, K., \& Golob, U. (2007). CSR expectations: The focus of corporate marketing. Corporate Communications: An International Journal, 12(4), 326-340.

Pomering, A., \& Dolnicar, S. (2009). Assessing the prerequisite of successful CSRI implementation: Are consumers aware of CSRI activities. Journal of Business Ethics, 85(2), 285-301.

Quazi, A. M. (1997). Corporate social responsibility in diverse environments: A comparative study of managerial attitudes in Australia and Bangladesh. Business \& Professional Ethics Journal, 16(4), 67-84.

Sen, S., Bhattacharya, C. B., \& Korschun, D. (2006). The role of corporate social responsibility in strengthening multiple stakeholder relationships: A field experiment. Journal of the Academy of Marketing science, 34(2), 158-166.

Trebeck, K. (2008). Exploring the responsiveness of companies: Corporate social responsibility to stakeholders. Social Responsibility Journal, 4(3), 349-365.

World Business Council for Sustainable Development (WBCSD). (1999). Corporate social responsibility: World business council for sustainable development. London: Red Letter Design.

Yoon, Y., Gurhan-Canli, Z., \& Schwarz, N. (2006). The effect of corporate social responsibility (CSR) activities on companies with bad reputations. Journal of Consumer Psychology, 16(4), 377-390. 